\title{
Entre a crítica ao ceticismo e uma filosofia positiva: considerações a partir de "Ceticismo dogmático e dogmatismo sem dogmas" de Plínio J. Smith
}

\author{
Roberto Bolzani Filho \\ Universidade de São Paulo \\ robertof@usp.br
}

resumo Este texto visa a desenvolver algumas análises filosóficas a respeito das ricas e intrincadas relações ent re ceticis mo e dogmatis mo, toma ndo como referênc ia o artigo de Plínio J. Smith intitulado "Ceticismo dogmático e dogmatismo sem dogmas", que, por sua vez, empreende uma análise crítica de textos por mim anteriormente elabora dos. Procuro aqui, sobretudo, retomar um ponto problemático que o referido artigo bem comenta, dele me servindo para avançar algumas novas formulações para uma posição crítia perante o ceticismo.

palavras-chave ceticismo; dogmatismo; metafilosofia; estruturalismo; justificação

Quando temos o pouco freqüente privilégio de observar que nossos próprios textos foram lidos e comentados, recebendo de alguém o mesmo tratamento que costumamos todos dar às produções dos filósofos, podemos experimentar variadas impressões. Eis algumas delas, mencionadas sem uma ordem rígida:

1. a impressão de ter sido mal lido, quando nosso leitor revela, em seu comentário, que não compreendeu suficientemente o que quisemos dizer.

2. a impressão de constatar, em virtude de justas conclusões extraídas por nosso leitor em seu comentário, que nem sempre conseguimos expressar com a clareza e a exatidão desejadas e imaginadas o que queríamos dizer; neste caso, eventuais mal-entendidos devem- se a nós e não a nosso leitor.

Recebido em 14 de abril de 2007. Aceito em 20 de setembro de 2007.

doispontos, Curitiba, São Carlos, vol. 4, n. 2, p.61-80, outubro, 2007 


\section{2}

3. a impressão de que a leitura feita termina por confirmar algumas suspeitas ou desconfianças que nós mesmos, os próprios autores, alimentávamos a respeito de nossos pensamentos, idéias ou argumentos, que já se nos manifestavam como problemas ou dificuldades que não sabíamos então como tratar e talvez ainda não saibamos.

4. a impressão de que tal leitura e comentário apontam para a existência de problemas que até então não eram vistos por nós como tais e que será preciso enfrentar, para descobrir se de fato o são e, doravante, assumir a tarefa de descobrir como tratá-los e, quem sabe, resolvê-los.

5. a impressão de uma espécie de gratidão pela leitura atenta e o comentário relevante e instrutivo, que quase nos convencem de que somos realmente capazes de pensar com profundidade.

Faço esta breve listagem para poder, agora, referir-me a "meu leitor e comentador": meu colega, interlocutor e amigo Plínio Junqueira Smith, com quem, há algum tempo, venho discutindo questões de filosofia, sempre pelo prisma da relação ao mesmo tempo polêmica e fascinante entre ceticismo e dogmatismo, e sempre sob a inspiração e influência de nosso mestre e amigo comum Oswaldo Porchat. De fato, ultimamente temos feito um esforço de reflexão filosófica, cada um a seu modo e ele com mais assiduidade e consistência do que eu, no qual provavelmente a longa convivência nos conduziu a reciprocamente tomar nossas idéias pessoais sobre o referido tema como uma espécie de ponto de apoio, ambos estando, ao mesmo tempo, definitivamente marcados pela admirável forma de filosofar de nosso mestre. Assim, algumas de nossas posições pessoais sobre ceticismo e dogmatismo têm-se apresentado, para nós mesmos e para os outros, a partir de comentários que fazemos sobre os textos que andamos produzindo sobre o assunto. Eu próprio, recentemente, publiquei um artigo intitulado "Ceticismo como autobiografia e autoterapia” (BOLZANI FILHO, 2005), no qual fiz uma análise e comentário crítico do ensaio de Plínio intitulado "Terapia e vida comum" (SMITH, 2005)1. Este texto, por sua vez, ao formular a versão do ceticismo que ele passou a professar, também continha algumas referências a posições minhas. Agora, dando continuidade a nosso diálogo, tenho diante de mim um artigo de Plínio denominado "Ceticismo dogmático e dogmatismo sem dogmas" (SMITH, 2006), no qual meu amigo se propõe a examinar alguns textos que escrevi sobre nosso assun- 
to favorito. $\mathrm{O}$ caráter polêmico de seu artigo revela-se já no título: um oxímoro, "ceticismo dogmático"; e um paradoxo, “dogmatismo sem dogmas". Eu gostaria de tecer aqui algumas considerações a respeito desse instigante, provocativo e, devo reconhecer, profundo e pertinente conjunto de comentários críticos dirigidos às idéias que propus.

Voltemos então àquela listagem inicial, sobre as impressões que nos acometem quando temos nossos próprios textos lidos por alguém. Daquelas impressões mencionadas, durante minha leitura do texto de Plínio eu experimentei a impressão 5 o tempo todo: afinal, é lícito que nos sintamos gratificados e até envaidecidos, quando podemos gozar do privilégio de ser lidos com a profundidade e atenção que desejamos todos que se dediquem a nossos textos. Em nenhum momento tive a impressão 1: a leitura feita por Plínio é certeira e sempre bem fundamentada, o que não surpreende aqueles que o conhecem. Com alguma freqüência experimentei a impressão 2, o que não é senão muito natural, porque, sabemos todos muito bem, um dos fenômenos mais corriqueiros na elaboração de textos, e talvez especialmente nos textos filosóficos, é nossa dificuldade de expressar com felicidade o que queremos dizer, o que torna também natural que se produzam sobre eles análises razoáveis que eventualmente não atinjam seu alvo com precisão, porque faltou plena clareza à expressão do autor. Pelo menos em uma ocasião, bastante significativa, passei pela impressão 3, como veremos daqui a pouco: Plínio tocou num ponto delicado de minhas idéias, e eu sempre achei que realmente havia ali algo mais complicado do que à primeira vista poderia parecer. Quanto à impressão 4, certamente a mais importante, porque pega o autor do texto criticado de surpresa, a ponto de às vezes retirar-lhe o chão, conduzindoo a refazer todo o seu trajeto de pensamento para tentar aperfeiçoá-lo, espero, num futuro próximo edescobrir se o fato de tê-la experimentado - pois isto ocorreu - me conduzirá a caminhos sem saída.

Em face de tão variada gama de impressões, não me propore aqui, evidentemente, a tratar de todos os temas e pro blemas - e são vários levantados por Plínio, não somente pelo tempo que isso demandaria, mas também, e principalmente, p orque somente um amadurecimento de meu próprio pensamento me permitiria descobrir o que posso dizer sobre eles. Espero que um dia eu seja capaz de prestar contas a mim mesmo, a Plínio e a todos a respeito desses problemas e temas. 
Resta-me então, agora, tratar apenas do que caracterizei pela impressão 3 , isto é, creio que Plínio observou muito bem algo que sempre me incomodou nos textos meus que ele examina. Essa impressão, eu a tive na leitura de algumas páginas de seu texto (SMITH, 2006, p. 172-4), porque, quando escrevi os dois artigos principais que ele analisa - "A epokhé cética e seus pressupostos" (BOLZANI FILHO, 1996) e "Oswaldo Porchat, a filosofia e algumas "necessidades de essência", (BOLZANI FILHO, 2003) -, dei-me conta de que o tipo de crítica que eu propunha ao cético, desenvolvida no primeiro deles, me obrigaria a fazer incursão por algo como, para retomar a expressão um tanto eloqüente e até pomposa que utilizei, uma metafilosofia. Noutras palavras, p recisei me pro nunciar sobre um assunto, como todos sabemos, extremamente polêmico: a definição mesma de filosofia, as características próprias do discurso filosófico - na expressão bastante forte do título do segundo artigo, onde faço semelhante incursão, aventuri-me a discorrer sobre suas "necessidades de essência".

Ora, ao fazer semelhante incursão metafilosófica - e aqui começamos a tocar em nosso ponto -, deixei ao menos fortemente sugerida, já na terminologia acima mencionada, a possibilidade de algum tipo de dogmatismo a ser futuramente construído, e Plínio assim o compre e ndeu, como deixam claro as seguintes afirmações suas: "Assim, uma questão acerca do sentido mais geral da reflexão de Roberto é saber se ele pretende somente uma crítica no sentido acima definido, que se limita a descrever as condições de possibilidade de todo e qualquer discurso filosófico, ou se ele pretende uma filosofia que estabeleça verdades filosóficas sobre objetos metafisicos; ou se essas duas pretensões combinam-se em uma única filosofia" (SMITH, 2006, p. 174).

Fazem-se necessários alguns esclarecimentos. Com efeito, no primeiro texto, propus um tipo de crítica ao ceticismo que não me parecia, stricto sensu, uma refutação à maneira tradicional, pois eu não pretendia constru i r um dogmatismo, um sistema dogmático de verdades, para então colocálo diante do cético e alegar que tal sistema seria imune aos seus argumentos e dúvidas. Eu me voltara para o que ali realmente chamei, em alguns momentos, de "explicação filosófica" do ceticismo, de sua "justi- 
ficativa" - como bem observou Plínio, para "um discurso em que (o cético) caracteriza seu próprio pensamento e descreve retrospectivamente sua trajetória” (SMITH, 2006, p. 172)2. Prossegue Plínio, mais uma vez comentando com precisão o tipo de crítica que pretendi desenvolver: "Nessa descrição de sua trajetória, o cético elabora um discurso próprio, assumido francamente como sua posição filosófica...Ora, ao oferecer uma caracterização desse modo de pensar, o cético abre o flanco para ser examinado como uma filosofia específica. $O$ exame e a avaliação dessa caracterização do modo cético de filosofar consiste na crítica à filosofia cética. A idéia central de Roberto é que o exame do ceticismo revela que este tem pressupostos implícitos, e a avaliação mostraria que esses são questionáveis, integrando o conflito das filosofias tanto quanto as teses dogmáticas" (SMITH, 2006, p. 172).

Não é o caso agora de nos voltarmos a tais “pressupostos", que julguei encontrar no discurso do cético, para neles nos determos, pois isto nos afastaria demasiadamente de nossos objetivos. Registro apenas, novamente me servindo da correta descrição do próprio Plínio, que pretendi acusar, na explicação que o cético faz de seu trajeto filosófico, "uma concepção pragmática, naturalista e biologista da razão humana" (SMITH, 2006, p. 172), que operava na maneira como o cético - e estou pensando em algumas passagens das Hipotiposes Pirrônicas de Sexto Empírico, além de certos momentos dos textos de Porchat - explicava ou justificava sua adoção de uma disposição permanente para a antítese e para a suspensão de juízo, a partir das experiências pontuais e particulares de investigações críticas das teses dogmáticas, que, indutivamente, o levariam a adotar uma nova postura, agora cética. Noutra palavras, sua transformação em cético dever-se-ia a uma concepção de racionalidade que nunca teria sido posta em questão por ele, nem sequer o poderia. Ora, todo o desafio, agora, consistia em mostrar que essa concepção de racionalidade operava então como um "pressuposto", sendo necessário ainda estabelecer por que isso acarretaria uma efetiva dificuldade para o discurso em que o cético explica e justifica seu ceticismo, já que minha idéia era capturar o cético naquela mesma armadilha formal que ele sempre soube montar com habilidade nos caminhos dogmáticos, detectando assunções injustificadas de hipóteses, petições de princípio e movimentos circulares nas pretensas demonstrações de seus adversários. 
Foi isso o que motivou o segundo texto, que pretendeu, em poucas palavras, recusar a alegação do cético - agora, nosso mestre comum Oswaldo Porchat é visado em primeiro plano - de que aquele discurso que considerei explicativo e justificativo efetivamente "diz apenas o que aparece" ao cético. Se assim for, dirá esse mesmo cético, não haverá como pretender denunciar pressupostos, pois isso se baseará numa má compreensão do estatuto meramente fenomênico do ceticismo e de todo o seu discurso, inclusive daquele que o descreve - pois será melhor dizer, nesse caso, que tal discurso "descreve" o trajeto intelectual do cético, e não que o "explica" ou "justifica", como pretendi. O próprio Plínio, diga-se de passagem, preferiu, como vimos, a terminologia da "descrição", ao referir-se ao discurso do cético, tal como por mim abordado, e também ao descrever minha própria posição.

Pareceu-me então que o próximo passo a ser dado consistia no que eu mesmo chamei de "observações metafilosóficas" sobre a "natureza" e "sentido" do discurso filosófico (Cf. BOLZANI FILHO, 2003, p. 94). Com isso pretendi, na verdade, justificar a estratégia adotada no primeiro texto, sem a qual a crítica não se poderia fazer: considerar o "discurso explicativo" ou "justificativo" do ceticismo como muito mais do que uma "descrição" - a saber, como um "discurso de instauração filosófica". Tentei mostrar que tal discurso do cético, mesmo se não pretende "pôr o que diz como real", o que evidentemente o distancia léguas dos dogmatismos, "instaura", por assim dizer, alguma coisa - instaura-se a si mesmo, como fazem todos os dogmatismos. Aqui, já adentrei no terreno mais pantanoso de meu trajeto: o recurso ao chamado "método estrutural" de análise de textos filosóficos, recurso esse que produziu, em meu texto, seus momentos provavelmente mais especulativos, pois a exploração das principais características filosóficas de tal método conduziu-me a falar de distinções como aquela entre "verdade material" e "ve rdade formal", distinção que me levou a usar a polêmica expressão "verdades filosóficas", em contraste com as pretensas verdades científicas sobre o mundo, e a referir-me a um certo "espaço filosófico" (Cf. BOLZANI FILHO, 2003, p. 104), além de recorrer a "distinções de razão" e outras bizarrias...Tudo isso é, reconheço, um tanto tenebroso, até arrepiante, e não posso senão conceder a Plínio que muito do que digo aí é, para dizer o mínimo, discutível, se não irremediavelmente problemático. 
Mas estou desviando-me de meu assunto e devo então voltar a ele. Para mostrar que o discurso cético contém certas características típicas dos dogmatismos, eu me vi conduzido a explorar o potencial filosófico da concepção de filosofia que considerei inerente ao método estrutural. O que me levou a uma análise dos dogmatismos - tomando o cartesianismo como caso privilegiado -, visando-os sobretudo como discursos metafísicos que essencialmente são. E defendi então a tese de que a metafísica moderna, pelo menos parte dela, consciente de que lida com objetos que não podem ser comentados e explicados à luz de critérios estritamente empíricos, encontrou em sua capacidade sistemática e arquitetônica a maneira de construir a evidência desejada às teses defendidas e argumentadas em seus discursos, o que daria a certas análises feitas pelos partidários do referido método estrutural boas razões para afirmar que a verdade a que aspiram está na "via", no "movimento" que conduz à tese defendida. Tudo isso ainda me parece relevante, embora eu tenha de admitir, dando razão a Plínio, que não poucas dificuldades surgem, não sendo a menor delas o fato de que isto soa talvez razoável e convincente a propósito de um Descartes; mas as filosofias - inclusive as metafísicas -, como bem sabemos, não se resumem ao cartesianismo e não se apresentam necessariamente como edificios construídos com a impecável unidade que nele se descobre.

Espero poder tratar com mais cuidado e atenção da questão do método estrutural noutra oportunidade, pois não posso negar que tem importância considerável e até mesmo decisiva nos dois textos referidos. Mesmo porque, como já mencionei, Plínio apresenta ponderações importantes a esse respeito, as quais não posso nem pretendo ignorar (Cf. SMITH, 2006, p. 176-7). Seja como for, pareceu-me, com base em tais análises, que o pirronismo e o neopirronismo, sobretudo este último, porque nascido num contexto filosófico contemporâneo, acolhem e exercitam características que os próprios céticos se comprazem em descobrir e rotular como marcas de dogmatismo, mesmo se o discurso dos céticos, inclusive aquele em que explicam e justificam sua filosofia cética, não se pretende "verdadeiro" à maneira dogmática. E uma dessas características terá sido a aspiração arquitetônica de seu discurso, que, então, mais do que descritivo, faz-se explicativo e justificativo do trajeto filosófico para o ceticismo. Refiro outras características comuns, apenas 
para diminuir a obscuridade de meu relato: certa busca de autonomia e exclusão das outras filosofias, garantida, no caso do ceticismo, não pela descoberta de qualquer verdade, mas pela dimensão terapêutica da antítese argumentativa dirigida ao interlocutor dogmático, o que tornaria o ceticismo, se não a filosofia verdadeira, ao menos aquela que pretende exercitar a sã racionalidade; certa universalidade, garantida pela origem do ceticismo, a busca da verdade, comum com a dos dogmáticos, mas cujo resultado original proporciona uma desqualificação de todas as formas filosóficas de dogmatismo; até mesmo certo tipo de perenização, garantida pela capacidade de reformulação do campo fenomênico; e um desejo, a meu ver irrefreável, de conversão do interlocutor dogmático em favor da filosofia cética ${ }^{3}$.

Talvez, agora, estejamos em condições de chegar ao ponto que nos interessava desde o início.

O ponto, então, é que alguém poderia perguntar:"supondo que você tenha razão; admitindo que exista um discurso explicativo e justificativo do ceticismo, não meramente descritivo, que ele contenha características filosóficas suficientes para ser lido à maneira dos discursos dogmáticos e que possa, portanto, trair a presença de pressupostos problemáticos que o integrem ao conflito das filosofias: qual é, então, o próximo passo? O que fazemos agora?"

Esta pergunta, eu a formulei a mim mesmo algumas vezes, durante a elaboração do segundo texto - cujo conteúdo, aliás, a presentei parcialmente por alguns anos em nossos colóquios - e mesmo também após essa elaboração ${ }^{4}$. Hoje, ainda não sei respondê-la. E nas ocasiões em que me tem sido possível refazer todo o trajeto que a ela me conduziu, renovo essa sensação de perplexidade.

Plínio viu nisso, com razão, uma espécie de "hesitação" e "ambigüidade", e vale a pena retomar seus termos: "Um ponto, entretanto, permanece ambíguo na posição esboçada por Roberto. De um lado, ele diz que o problema da refutação do ceticismo que recorre ao senso comum ou à Vida Comum é admitir somente um reduzido e seleto núcleo de verdades pré-filosóficas, concedendo tudo, em filosofia, ao ceticismo. Como vimos, essa via de refutação do ceticismo parece insatisfatória a Roberto. Mas qual a razão invocada por Roberto? Qual a sua insatisfação com esse tipo de resposta ao ceticismo? A razão principal, a 
meu ver, é que ele quer 'verdades filosóficas'. A idéia mesma de uma crítica ao ceticismo sugere, contudo, que não se pretende estabelecer verdade nenhuma, mas somente denunciar uma contradição inerente ao discurso cético, já que este deve necessariamente se comprometer com pressupostos dogmáticos para que seu discurso tenha sentido. Não está muito clara a relação entre esses dois lados do pensamento de Roberto. Talvez ocorra uma hesitação similar quando Roberto parece oscilar entre a idéia de simplesmente enumerar e comentar as exigências necessárias do discurso filosófico e a idéia de garantir a autonomia da filosofia como um discurso cognitio diferente das ciências, mas que tem objetos, procedimentos demonstrativos e ve rdades próprias. Não está claro se ele pensa que a crítica filosófica que empreende pode resultar em algum conhecimento especificamente filosófico ou se somente descreverá as condições de possibilidade de todo e qualquer discurso filosófico. Assim, uma questão acerca do sentido mais geral da reflexão de Roberto é saber se ele pretende somente uma crítica no sentido acima definido, que se limita a descrever as condições de possibilidade de todo e qualquer discurso filosófico, ou se ele pretende uma filosofia que estabeleça verdades filosóficas sobre objetos metafisicos; ou se essas duas pretensões combinam-se em uma única filosofia" (SMITH, 2006, p. 173-4).

Eu não endossaria algumas poucas formulações desta passagem do texto de Plínio, mas não posso senão reconhecer a presença de tal ambigüidade e hesitação, deixadas fortemente sugeridas por meus dois textos.

Vejamos com mais vagar como compreender essa ambigüidade e hesitação. Eu as formularia assim: a crítica que propus em "A epokhé cética e seus pressupostos" (BOLZANI FILHO, R. 1996.) tinha seus próprios pressupostos, que se podem resumir na tese de que há um "discurso de instauração filosófica" no ceticismo, tese que se fundamentava numa concepção de filosofia e discurso filosófico baseada na metodologia estruturalista, que diz que os discursos filosóficos "instauram" o real. Tratava-se, contudo, de um texto crítico, "dialético", por que não dizer, que propunha, em vez de uma "refutação defensiva" do ceticismo que o afastasse mediante mais uma versão do dogmatismo, uma "crítica ofensiva" que não precisava, para tanto, pôr nenhuma tese dogmática sobre a realidade (Cf. BOLZANI FILHO, 1996, p. 41). Mas então não se justificava ainda o lugar a partir do qual essa crítica se fazia - essa a tare fa do 
segundo texto, “O swaldo Porchat...” (BOLZANI FILHO, R . 2003). E esse lugar foi aí caracterizado como "metafilosófico", isto é, um ponto de vista do qual não se fala sobre o mundo, mas sobre a própria filosofia, de forma ao mesmo tempo descritiva e prescritiva, descobrindo "condições de possibilidade" e enumerando "necessidades de essência", sem deixar, para isso, de fazer uma espécie de defesa e até elogio do discurso metafisico. "Muita pretensão e imprudência para um único texto", pensará decerto o leitor ou ouvinte mais calejado no trabalho do pensamento.

Pa receu então a Plínio, com razão, que este segundo texto projetava ou parecia projetar - a expressão é minha - uma espécie de programa dogmático de investigação filosófica que eu naturalmente deveria agora empreender. E a mim sempre ficou a sensação de que haveria um próximo passo a dar, sem saber exatamente, no entanto, qual seria. Cabe-me agora, como ele parece aventar, construir uma metafísica própria? Eu não o pretendi e me parece que isso seria apenas um retorno a um tipo de filosofia dogmática tradicional; e não estou certo de que é isso que estou obrigado a empreender, ou mesmo se estou obrigado a dar um próximo passo em direção semelhante. O próprio Plínio, creio, não chegou a dizê-lo, limitando-se a uma análise de possibilidades que, no entanto, lhe permitiu acertadamente detectar uma dificuldade que poderá se afigurar um impasse.

A impressão de que propus uma espécie de programa filosófico a cumprir no futuro se choca, de fato, com a maneira como terminei "A epokhé cética e seus pressupostos" (BOLZANI FILHO, R. 1996). Pois ali eu concluía que, se é certo que o discurso filosófico cético só se sustenta filosoficamente - só se "instaura”, para usar o vocabulário estruturalista que elegi -, porque porta em seu interior seus pressupostos próprios, então, como bem observa e descreve Plínio, "o ceticismo é opcional, de modo que, mesmo se não aceitarmos nenhuma forma de dogmatismo, não estamos obrigados, ou condenados, a ser céticos" (SMITH, 2006, p. 175).

De fato, o penúltimo parágrafo de meu texto terminava concluindo: "suspender o juízo sobre certas questões e temas, filosóficos ou não, reconhecendo a eficácia de toda argumentação antitética que o 'cético' perante a nossa possa apresentar, deve significar inevitavelmente $e$ se ainda pretendemos filosofar, assumir um ceticismo, ser cético necessariamente?" (BOLZANI FILHO, 1996, p. 56). 
Não posso negar que, nesse momento quase derradeiro daquele texto, eu fazia essas afirmações com o objetivo de equiparar o ceticismo aos dogmatismos, sem categoricamente desqualificá-lo, sem "refutá-lo". Minha intenção, como se pode constatar, foi apenas estabelecer o seguinte ponto: se não pudermos refutar os argumentos que o cético dirige a nossa filosofia, não precisaremos ser necessariamente conve rtidos a ceticismo. E nada se dizia ou sugeria sobre o que poderíamos ser além disso. Ora, também não posso negar que a "metafilosofia" proposta no texto seguinte, que visa a fundamentar o primeiro assume certo tom dogmático, embora eu acredite que esse dogmatismo é mais claramente assumido no texto que escrevi a respeito do "ceticismo depurado" de Plínio do que nos dois textos aqui referidos ${ }^{5}$. No segundo deles, como o próprio Plínio chega a comentar, emprego a expressão "doente de dogmatismo" em sentido um tanto irônico (cf. SMITH, 2006, p. 181) ${ }^{6}$.

Seja como for, minha dúvida, que é também de Plínio, diz respeito a tal dogmatismo. Eu já me perguntava seriamente e, agora, após ler o texto de Plínio, faço-o mais preocupado: tal "d ogmatismo metafilosófico" me obriga a construir um dogmatismo aos moldes da tradição? Creio que não, seria muito forte dizer que estou obrigado a isso - Plínio, aliás, como observei, não usou semelhante terminologia. Mas então eu estarei talvez condenado a uma espécie de aporia filosófica, constatando finalmente que eu andara todo o tempo por uma rua sem saída? Ou talvez seja preciso dizer: estarei fadado a uma metafilosofia dogmática que se esgota filosoficamente ao descobrir aquilo que Plínio chamou de "condições de possibilidade" dos discursos filosóficos, retomando expressão minha? Será, então, que o resultado a que cheguei consiste na conclusão de que, doravante, caberá ao filósofo a função de guardião de tais condições de possibilidade, avaliando os discursos que se pretendem filosóficos para então julgar se realmente o são, tomando por critério aquelas famigeradas "necessidades de essência"? Ou então, se for verdade que não há discurso filosófico possível que não exiba tais características, passará a ser a tarefa única do filósofo analisar os discursos filosóficos e mostrar a presença de tais características, eventualmente à revelia de seus autores, como seria o caso do discurso cético, reproduzindo e reforçando ad nauseam uma tese que nada quer dizer sobre o mundo, porque não se dirige a ele? 
Neste caso, o final de nossa estória poderá ser pior: tornar-se-á o próximo passo que darei a resoluta mas infeliz descoberta de que todo e qualquer discurso filosófico, seja dogmático seja cético, está tragicamente destinado a exercitar um conjunto de leis do gênero, exibindo a destreza e maestria de seu criador, mas que, ao fim e ao cabo, se revelaria portador de circularidades, petições de princípio, argumentos de autoridade e tudo o mais que os filósofos se comprazem em detectar em seus interlocutores adversários, transformando-se talvez em meros jogos de palavras aos quais não mais fará sentido solicitar que nos esclareçam sobre expressões como "verdade" e "razão"? Ainda que um tanto artificialmente dramático, este desfecho não pode ser ignorado aqui. Não estarei, afinal, apenas assumindo uma herança maldita e confirmando a incomensurabilidade das filosofias, em consonância com a metafilosofia de forte inspiração estruturalista que mobilizei, ao mesmo tempo transformando a filosofia numa forma que deve e somente pode ser exercitada, se desprovida de todo e qualquer interesse por dizer como as coisas são bem como pela possibilidade de suspender o juízo a esse respeito? O lugar a que se chega, nesse caso, é, em medida importante, anterior à própria distinção entre ceticismo e dogmatismo, porque o filósofo transita num âmbito metafilosófico. E isso significaria que o próprio ceticismo, ao contrário do que pretendia, estaria sujeito às limitações mencionadas. Mas o que, então, restará a dizer sobre os discursos filosóficos em geral, exceto que eles devem obedecer a certos preceitos específicos de seu gênero?

Como, mais uma vez, bem observou Plínio, busquei nos meus textos colocar o cético num dilema, que ele assim expressa: "ou aceitar seus pressupostos para que seu modo cético de filosofar esteja justificado, incorrendo assim em dogmatismo; ou abandonar esses pressupostos e, assim, perder todo e qualquer poder de converter seus leitores ao ceticismo... Roberto veria, não tanto na dúvida cética, mas no discurso cético, uma alternativa filosófica que somente seria possível se certos pressupostos fossem aceitos previamente. Mas, se aceitarmos esses pressupostos, seremos dogmáticos, pois são questionáveis e controversos. E, se não aceitarmos, é o próprio discurso cético que perde seu sentido" (SMITH, 2006, p.173). Parece-me agora que eu mesmo poderei estar sujeito a outro dilema: ou tentar empreender a refutação do ceticismo à maneira tradicional, ofe recendo uma filosofia cuja verdade e evidência sobrepu- 
jem a força dos "argumentos céticos" - algo que, de fato, procurei evitar, pois, para dizer o mínimo, seria como tentar abraçar o mundo -, ou, seguindo a via metafilosófica acima descrita, reconhecer, ao fim e ao cabo, que ela não é prolegômeno a nenhuma filosofia futura e não nos leva a nenhum lugar filosoficamente relevante. O oxímoro conduziu ao paradoxo: o "ceticismo dogmático" que, inadvertidamente, sonhei denunciar no ceticismo, arrastou-me a um decepcionante e estéril "dogmatismo sem dogmas". Não posso negar a possibilidade de que, com o título de seu artigo, Plínio tenha logrado confirmar algo que eu mesmo já desconfiava ser um dilema real e incômodo, talvez um impasse.

Bem pesado tudo isso, mantenho, no entanto, uma convicção, que me faz ainda insistir nesta linha de análise cujas dificuldades acabo de reconhecer, orientado pelas pertinentes observações de Plínio. Para expressála, voltemos às linhas finais de "A epokhé cética e seus pressupostos", mas agora não ao penúltimo, e sim ao último parágrafo, que procurava, digamos assim, colher os frutos da estratégia anunciada no início do texto, e que agora cito: "Além disso, estas críticas procuraram, como se disse, pôr em xeque a idéia de uma prática aporética sistemática filosoficamente justificada.É o ‘ismo’ do ceticismo que se colocou em questão. Ora, isso nos parece dar-lhes status de logicamente prévias à idéia mesma de uma 'refutação do ceticismo', dos 'argumentos céticos'. Pois é a própria necessidade de tal refutação que poderia ser repensada: não teríamos mais 'argumentos', pois não haveria o que defender por seu meio. Não haveria mais um ceticismo para além deles" (BOLZANI FILHO, 1996, p. 57).

Ora, enfocar o discurso explicativo e justificativo do ceticismo é uma forma de, antes de tentar empreender a tarefa hercúlea de sua refutação, descobrir se o cético está, afinal, capacitado filosoficamente a nos convencer de que ele tem boas razões para caracterizar sua filosofia como um exercício constante de crítica aos dogmatismos. E, se assim não for, poder-se-á ao menos concluir que nossa incapacidade - em princípio, pelo menos, nunca definitiva - de refutar tais argumentos não nos obriga a ser céticos, como eu disse nesse mesmo texto, já no penúltimo pará- 


\section{4}

grafo: "Estas tentativas de crítica, como se disse, não pretenderam, em nenhum momento, dizer respeito aos argumentos que o ceticismo nos apresentou e ainda apresenta. Mas, se não se refutam os chamados 'argumentos céticos', qual a re l evância de tais críticas? Parece-nos que elas têm como conseqüência justificar a colocação de tais argumentos em um lugar que já os dogmatismos modernos clássicos, como os de Descartes e Berkeley, de modo excessivamente natural haviam definido: o de etapa prévia ou concomitante a uma real investigação da verdade. Por meio delas, cabe perguntar se o poder de tais argumentos 'céticos' - que, afinal, não são chamados assim senão provisoriamente - deve levar-nos, necessariamente, a uma filosofia cética ou, como única alternativa concebível, à renúncia à filosofia; se é isento de problemas construir, por detrás e a partir dessa incontestável força dialética, um conjunto de justificativas para um modo de pensar que se torne permanente para o investigador" (BOLZANI FILHO, 1996, p. 56).

Creio que se pode apreender claramente, por estas linhas finais do referido artigo, que o dilema a que tentei levar o cético fora, afinal, uma tentativa de escapar de um outro dilema, que o próprio cético me parecia propor: ou refutar os argumentos céticos, ou render-se ao ceticismo. Pedindo-lhe que se explicasse sobre seu ceticismo, eu estava adiando esse desafio, alegando que não estava obrigado a aceitá-lo e, principalmente, condicionando essa possível aceitação a uma razoável resposta oferecida pelo cético à questão: por que ele faz a crítica dos dogmatismos?

Com isso, eu pretendia evitar o que me parecia um tradicional equívoco dos filósofos clássicos, quando aceitavam o desafio cético, e para isso tomei como exemplos Descartes e Berkeley. Cada um a seu modo, eles simplesmente ignoraram o fato de que o ceticismo é uma disposição filosófica, partindo diretamente para a refutação de seus argumentos. E o fizeram, porque não viam sequer um mínimo de plausibilidade na idéia de que o ceticismo pudesse reivindicar o direito de ser uma filosofia. Digamos então que, no que diz respeito às suas relações filosóficas com o ceticismo, eram representantes de um dogmatismo "não-crítico", isto é, despreocupado com indagar se o cético tem boas razões para fazer o que faz. Chamemos então seu dogmatismo, além de "não-crítico", de "refutativo".

Ora, ao fazer a "crítica" e não a "refutação" do ceticismo, pretendi, portanto, levá-lo filosoficamente a sério, dife rentemente de boa parte dos 
dogmatismos que se voltaram para os "argumentos céticos" ou "dúvidas céticas". Diferentemente, por exemplo, de um Descartes ou de um Berkeley, não reduzi o ceticismo a um simples agregado de argumentos críticos que qualquer um poderia propor e que existiriam apenas para que pudéssemos derrubar: nele vi a possibilidade de uma filosofia da argumentação antitética e crítica. Peço então que me concedam a prerrogativa de caracterizar minha estratégia como a de um "dogmatismo crítico".

A esse respeito, creio ser necessário fazer alguns esclarecimentos, sobretudo porque os comentários de Plínio mostram que não fui suficientemente claro sobre os motivos que me conduziram a propor tal estratégia crítica. Baseado nas primeiras páginas de meu artigo, ele descreve minha estratégia de incidir sobre o discurso que explica e justifica o ceticismo, lembrando que inicialmente eu me referia às estratégias de refutação de que em seguida iria me afastar: estabelecer verdades filosóficas imunes aos argumentos céticos ou preservar um núcleo de verdades comuns e não-filosóficas, também imunes a tais argumentos. A seguir observa: "Roberto não crê que essas maneiras de refutar o ceticismo sejam plausíveis. No primeiro caso, porque cada filosofia que pretende estabelecer uma verdade definitiva deve desqualificar as demais filosofias, isto é, deve enfrentar todas ou, ao menos, boa parte das filosofias elaboradas ao longo da história da filosofia, e essa é, talvez, uma tare fa insuperável. No segundo caso, a refutação do ceticismo não somente recorre a um núcleo reduzido e seleto de verdades, como também admite somente verdades pré-filosóficas, concedendo ao ceticismo total domínio no campo da filosofia" (SMITH, 2006, p. 172)

A descrição é quase sempre certeira. Quase sempre, porque não pretendi negar plausibilidade a essas estratégias de refutação, embora eu tenha de reconhecer que não me expressei de maneira categórica a esse respeito. Também não pretendi propor que a tarefa de refutar o ceticismo pela primeira estratégia pudesse ser insuperável - afirmei que "as dificuldades desse empreendimento são notórias" (BOLZANI FILHO, 1996, p. 38). Mas não há dúvida de que procurei caracterizar as limitações envolvidas nessas formas de refutação em termos muito próximos aos que Plínio utilizou. Contudo, constato que não fui eficaz ao propor minha estratégia, p o rque pareceu a Plínio que, ao iniciar sua justificativa, eu passava a fazer "considerações gerais adicionais de por que a estratégia de 
refutação do ceticismo estaria fadada ao fracasso" (SMITH, 2006, p. 172). Embora eu não tenha pretendido condenar ao "fracasso" as tentativas de refutação, Plínio descreve adequadamente minhas ponderações: "como incidem sobre os argumentos que os céticos propõem, essas duas espécies de refutação (a filosófica e a não-filosófica) não podem senão fracassar, já que não entendem o papel desempenhado pelos assim chamados argumentos céticos e desconhecem a natureza do ceticismo. A refutação do ceticismo por meio da tematização dos argumentos céticos ignora o fato de que o ceticismo não se define por esses argumentos. Propriamente falando, não há argumentos céticos, mas somente argumentos dogmáticos que sustentam teses dogmáticas contrárias entre si. Essa estratégia cometeria, assim, uma ignoratio elenchi, e procuraria atingir o cético num lugar em que este não se encontra” (SMITH, 2006, p. 172).

Em virtude da maneira talvez infeliz pela qual dispus minhas análises, sugeri a Plínio que passava a fazer aí algo "adicional", quando, na verdade, estava adentrando no ponto principal do que desejava dizer. Esse malentendido pode ter levado a outro, presente na seqüência da descrição de Plínio sobre minha estratégia crítica, pois ele prossegue nestes termos: "Uma vez que a refutação do ceticismo é uma via pouco promissora, resta-nos, então, segundo Roberto, a opção de criticar o ceticismo. Em vez de deixar o cético desferir o primeiro golpe e, depois, tentar reagir, golpeando o vazio, deveríamos tomar a iniciativa e abertamente criticá-lo no que propõe como alternativa aos dogmatismos" (SMITH, 2006, p. 172). Novamente, descrições precisas, mas a pouca ênfase por mim dada ao estatuto da crítica fez parecer que vejo a forma de crítica que proponho como um opção, assumida em virtude de ser a refutação "uma via pouco promissora". $\mathrm{Na}$ verdade, eu deveria ter sido mais incisivo ao introduzir o significado e estatuto da crítica que adoto, quando, em meu texto, indaguei: "Independentemente de seus resultados, por que essas duas vias de refutação se fazem passíveis de crítica?” (BOLZANI FILHO, 1996, p. 39) ${ }^{7}$.

Portanto, não é porque aquelas duas estratégias de refutação se têm revelado ineficazes - ineficácia que, no entanto, eu comentei no texto -, que se fará uma opção por um novo sentido de crítica: é porque se constata que somente assim se alcança real e filosoficamente o ceticismo, e isso nos conduz necessariamente a adotar semelhante procedimento crítico. Ora, 
parece-me então que um dogmatismo crítico não somente pode, como deve olhar para o ceticismo por esse prisma e solicitar-lhe um discurso explicativo e justificativo.

Creio que se pode justificar sem maiores dificuldades a pertinência e até naturalidade de tal estratégia e procedimento metodológico. Sabemos que o cético tradicionalmente formula sua posição como a busca da suspensão de juízo sobre qualquer tese que pretenda comentar a natureza da realidade, e que isso o faz exercitar o seguinte lema: "a todo argumento opor um argumento de igual força de persuasão", pois isto proporciona as condições à suspensão de juízo, isto é, eqüipotência persuasiva das teses em oposição. O cético, portanto, participa do diálogo filosófico sistemática e insistentemente apresentando, perante seus distintos e variados interlocutores, distintas e variadas antíteses, conforme as teses defendidas por eles, como deve ocorrer em boa dialética, porque sua intenção é conduzir a si mesmo e a seu interlocutor dogmático à suspensão.

Ora, o filósofo dogmático, por estar acostumado a presenciar a proposição de argumentos críticos, seja por ele próprio seja por outros filósofos dogmáticos como ele, tendo todos eles por objetivo, entretanto, minar os dogmatismos adversários, e tendo cada um deles em vista a defesa de seu próprio dogmatismo, poderá observar e acompanhar aquele procedimento antitético do cético; e é muito provável que constatará que, dife rentemente dele próprio e de seus rivais dogmáticos, o cético defende diferentes e até conflitantes teses em situações dialéticas distintas. Ontem, ele defendeu uma tese que ameaçava fortemente a posição defendida por um dogmático; hoje, está sustentando posição bem diferente, polemizando intensamente com outro dogmático e chegando mesmo a aproximar-se do dogmático que ontem criticou; amanhã talvez se posicione contra ambos...Aquele filósofo dogmático, mais observador, poderá então, de início, pensar consigo mesmo: "esse indivíduo é um inconseqüente" - para falar como Descartes e Berkeley, poderá concluir que tal indivíduo duvida por duvidar, de maneira inconseqüente e leviana, e que suas dúvidas são, afinal, artificiais e simuladas.

Contudo, num segundo momento, esse filósofo dogmático, ciente das dificuldades envolvidas em suas pretensões filosóficas, capaz que é de reconhecer que seus concorrentes dogmáticos via de regra exibem boas razões para defender suas posições - e talvez seja ele uma exceção em seu 
grupo -, poderá, por isso, se perguntar: "terá aquele indivíduo algum motivo razoável para proceder assim"? E porventura, refletindo sobre isso, poderá mesmo chegar a dirigir-se a esse indivíduo, que ele não sabe ainda que se define como um cético, para fazer-lhe a mesma pergunta que fez a si próprio: "por que você às vezes defende uma tese, às vezes outra, inclusive teses contrárias"?

Esse é o momento em que o cético, creio, não poderá furtar-se a fazer um "discurso explicativo" ou "justification" de sua posição - ou, ao menos, não poderá evitar que a "descrição" que faz de sua trajetória filosófica, da busca inicial da verdade até a prática antitética visando a suspensão de juízo, seja vista por seu interlocutor, ainda que à sua revelia, como uma "explicação" ou "justificação” dessa posição. Ora, é a esse discurso, assim me parece, que devemos nos voltar para avaliar o ceticismo como uma filosofia.

Semelhante atitude, que chamei aqui de dogmatismo crítico - neste caso não julgo haver oxímoro -, concede ao ceticismo, portanto, ao menos em princípio, a possibilidade de seu estatuto filosófico, ao mesmo tempo em que encontra o lugar correto ao qual dirigirá seu olhar crítico. Mas isso não elimina a possibilidade de que esse olhar crítico o leve, por que não, a aderir ao ceticismo. Po rque o que chamei aqui de dogmatismo crítico assume a possibilidade de uma conversão ao ceticismo, mas - e aqui está toda a diferença - não pode aceitar que o cético possa pretender convertê-lo apenas argumentando dialeticamente desde lugar nenhum.

Assim, será talvez mais clara a solicitação que fiz ao cético, quando, um tanto ironicamente, me referi à minha "doença dogmática", solicitação que me permito, por isso, agora reiterar: "Como 'doente de dogmatismo' a quem o cético deverá curar, não me contento com ver a noção de verdade denunciada em toda sua problematicidade, inclusive a partir de minhas próprias teses: quero também conhecer e avaliar a filosofia dessa denúncia, as razões internas que a justificam como filosofia" (BOLZANI FILHO, 2003, p. 112).

Para terminar, devo mais uma vez concordar com meu caro interlocutor: em consonância com sua própria concepção de filosofia, segundo a qual o diálogo deve nos auxiliar a compreender melhor nossos próprios pensamentos, Plínio introduziu suas análises sobre meus textos 
deixando claro que tinha a intenção de "contribuir para o eventual aperfeiçoamento" de minha posição (Cf. SMITH, 2006, p. 171). Creio que ele foi bem sucedido. Além de encontrar um ponto problemático em minhas idéias sobre ceticismo e dogmatismo, confirmando algo que sempre me incomodara, ele me mostrou que era preciso também formular melhor minhas razões para sustentar minha posição. E, ao fazê-lo, deime conta de que, se ainda for possível e frutíferopensar a filosofia nos termos dessa tão tradicional distinção entre dogmatismo e ceticismo, isso nos obriga a todos, céticos ou dogmáticos, a adotar uma atitude semelhante àquela que chamei aqui de crítica. Não digo aí nada que não tenha sido mais bem afirmado por filósofos. Mas lembrar disso, ironicamente, permite por assim dizer arejar a própria idéia de dogmatismo, que, se pode envolver presunção e precipitação, como queria já Sexto Empírico, não precisa e não deve, por isso, ser sinônimo de idiossincrasia e vaidade, como se fosse impossível a um filósofo pensar criticamente sem, para tanto, adotar alguma forma de ceticismo.

Portanto, a esse respeito, solicito aos céticos que permaneçam vigilantes. Durante séculos, eles foram vítimas de caricaturas a respeito de suas intenções filosóficas, sofrendo, nas penas de filósofos como Descartes e Berkel ey, grandes injustiças. É preciso evitá-las. Mas é preciso também estar atento para o risco de devolver aos dogmáticos outra caricatura, algo que talvez alguns desses mesmos céticos, voltados à elaboração filosófica de seu ceticismo, tenham, inconscientemente, logo aprendido a fazer.

${ }^{1}$ Originalmente publicado em BOLZANI FILHO, 1995. Mais recentemente, tive a oportunidade de retomar parcialmente o conteúdo de meu artigo a respeito deste ensaio de Plínio, quando se criou a revista Sképsis, que em seu número inicial, que acaba de ser lançado, apresenta um Book Symposion sobre sua coletânea de ensaios, do qual participei com um breve comentário. Plínio ali mesmo responde, a mim e aos colegas que também participaram: Eleonora Orlando e Waldomiro José da Silva Filho. Cf. Sképsis - Revista de Filosofia - ISSN 1981-4194 (www.revista-skepsis.com).

${ }^{2}$ Utilizei as expressões mencionadas em BOLZANI FILHO, 1996, p. 41.

${ }^{3}$ Acabo de retomar grosseiramente as análises que arrisquei em BOLZANI FILHO, 2003, p. 95-116.

${ }^{4}$ Este texto reproduz, com umas poucas modificações, o que apresentei no XII Colóquio Nacional sobre o Ceticismo Filosófico, organizado por Luiz Eva em Curitiba, na UFPR, em Maio 
de 2007. Recordo-me de ter falado a respeito destes assuntos na mesma Curitiba, há cerca de quinze anos, noutro colóquio sobre ceticismo. Os debates então ocorridos estimularam-me intensamente a prosseguir.

${ }^{5}$ Em "Ceticismo como autobiografia e autoterapia", afirmei peremptoriamente que, ao veicular certas exigências mínimas imprescindíveis a todos os discursos filosóficos, minha crítica ao "ceticismo depurado" de Plínio assumia seu teor dogmático, ainda que "fraco" e "moderado”. Cf. BOLZANI FILHO, 2005, p. 202.

${ }^{6}$ A expressão é deveras utilizada com aspas. Cf. BOLZANI FILHO, 2003, p. 112.

7 Itálicos acrescentados nesta citação.

\section{Referências bibliográficas}

BOLZANI FILHO, R 1995: Discurso, Revista do Departamento de Filosofia da USP, São Paulo, Discurso Editorial, n. 25, , p. 6995. 1996. A epokhé cética e seus pressupostos.

Discurso, Revista do Departamento de Filosofia da USP, São Paulo, n. 27, p. 37-60. 2003. Oswaldo Porchat, a filosofia e algumas "necessidades de essência". In SMITH, P. J. \& WRIGLEY, M. B (orgs.). O Filósofo e sua história: Uma homenagem a Oswaldo Porchat. Campinas: Editora da Unicamp, p. 87-130. 2005. Ceticismo como autobiografia e autoterapia. In SILVA FILHO, W. J. (org.). O Ceticismo e a possibilidade da filosofia. Ijuí: Editora da Unijuí, p. 181-208.

SMITH, P. J. 2005. Terapia e vida comum. In SMITH, P. J. Do começo da filosofia e outros ensaios. São Paulo: discurso editorial, p. 49-87. 2006. Ceticismo dogmático e dogmatismo sem dogmas. Integração, Centro de Pesquisa da Universidade São Judas Tadeu, São Paulo, ano XII, n. 45, abril/maio/junho, p. 171-85. 